Der Russen-Boom. Sowjetische Ausstellungen als Mittel der Diplomatie in der BRD. By Elena Korowin. Böhlau Verlag: Cologne, 2015. Das ostliche Europa: Kunstund Kulturgeschichte, no. 3. 312 pp. Notes. Bibliography. Index. Illustrations. Photographs. €39.90, hard bound.

doi: 10.1017/slr.2017.200

Does art play a role in international politics or diplomacy? The author of the book Der Russen-boom gives a convincing answer to this question: yes, because art is perceived as a visual sign of societies and their cultures, and as a field for internal and international politics. Art has many functions but also symbolizes forms of social reality. Art exhibitions and artists influence the image of the "other," in this case the Soviet Union and West Germany. Different state institutions or private collectors participate in the organization of exhibitions, thus networks and the communication between the two states became visible. Even though culture in the field of international politics is a soft skill, it allows many people to discover, via artefacts, the other country and to participate in ongoing debates. Whereas diplomacy is more hidden and exclusive, art exhibitions are open to a broader audience and can reach many people on a symbolic level. Cultural exchange happens via art, as Elena Korowin prooves in her study.

The author is an art historian. This book is her dissertation, which she defended in 2013. Her research covers the time period from the 1950s until the end of the Soviet Union. Her framework is a general and well-known timeline of Soviet history, form the first steps of opening the country to the west in the 1950s, through the new German politics at the beginning of the 1970s, to the wide liberalization and many reforms since Perestroika. The reader is introduced to the meaning of artists and learns about the controversial debate concerning their work and life, as for example Kasimir Malevich. Beyond an interesting specter of other actors, she describes art collectors such as Peter Ludwig in Cologne or Georgios Kostokin in Moscow. Art also interested diplomats like Vladimir Semenov. Without individuals and their expertise, most exhibits could not have been realized.

In the introduction, a short overview of cultural contacts between Germany and the Soviet Union are given: whereas there was a vivid exchange in the 1920s, political relations did change in the 1930s and especially with the Second World War. On May 30, 1959, an first agreement between the Soviet Union and West Germany was signed about culture. In the aftermath, a first exhibition with exponents from the Russian avant-garde was opened in the same year in Frankfurt am Main.

Methodologically, Elena Korowin focuses on important exhibitions, the organizers, and reactions in the press. She conducted oral history interviews with prominent art experts who were involved in the mentioned exhibitions, like Adolf Rieth, Klaus Gallwitz, or others. Often, these persons used personal contacts to get famous works of art or to organize an exhibition. Yet, it is unclear which criteria the author uses for judging which exhibitions were relevant and which unimportant.

In the first years of such cultural contacts, the Soviet Union was afraid of the impact of too much western influence, which was not regarded as positive for Soviet society. This argument vanished over the years. Art was also a way to earn money by selling artwork. In 1987, the Second World War and its consequences for both countries was still an important topic.

Because Elenea Koworin looks deep into newspaper articles and critiques of the exhibitions, her study lends profound insights into mutual understandings during the cold war. In the west there were many stereotypes. The artefacts shown always had the image of being instruments of "dissent," even though it was not always clear if the artists were really non-conformists or if some of their artwork was simply not shown. The author also discusses the perception of Malevich and his obvious turn 
in painting since 1930: was it due to the "Stalinist revolution" and some sort of inner migration or was it for non-political reasons? In West Germany there were few experts of Soviet art who influenced the opinion of a broader audience. On the other hand, organizing art exhibitions with German art in the Soviet Union was more difficult as there were officially no contacts with West Berlin, as well as state-imposed censorship. Over time, the contacts between museums widened. The study of art as a field of international relations is a valuable contribution to cultural studies of the Cold War and goes beyond art history.

CARMEN SCHEIDE Institute of History, University of Bern, Switzerland

\section{Money, Power, and Influence in Eighteenth-Century Lithuania. The Jews on the Radziwitt Estates. By Adam Teller. Stanford: Stanford University Press, 2016. xvi, 310 pp. Notes. Glossary. Bibliography. Index. Tables. Map. \$70.00, hard bound. \\ doi: 10.1017/slr.2017.201}

In recent years, scholars of Jewish history have (re-) discovered the Jewish economic encounter as an area with considerable potential to shed light on processes of societal integration or segregation, cultural transformation, and communal development. A prominent focus was trade networks as a core element in the functioning of a transnational Jewish community, and the interactions between Jewish and non-Jewish mercantile elites. The volume reviewed here, a translation of the doctoral dissertation of the author published in Hebrew in 2006, shifts the focus to the economic alliance between Polish-Lithuanian Jews and one magnate family, the Radziwiłłs, as it unfolded between the late 17th century and the partitions of Poland in the late 18th century. The core matters are well described in historical scholarship: the close cooperation of the PolishLithuanian aristocracy with Jewish leaseholders, their central role in the production and sale of alcohol (the so-called propinacja), the impressive demographic growth of Jewish communities on privately owned estates, the prominent role of Jews in wholesale and retail trade. The innovative, indeed pioneering achievement of this study is its review of the case of one latifundium, the estates of the Radziwiłl family, as reflected in the family's archive, by far the largest accessible archive of its kind.

As the author emphasizes on several occasions, the Radziwiłl-whose subsequent leading members are briefly introduced at the beginning-were not unique in their economic cooperation with Jews, but their archive offers unique insights into the unfolding of this cooperation, motivated by the objective to increase monetary revenue from the latifundium. In the first chapter, the author demonstrates that the considerable demographic growth of Jewish communities on the vast Radziwiłt estates-the estates owned by this family contained up to two thousand villages and urban settlements-was clearly the result of this strategy. The second chapter reflects the occupational structure of small and larger urban settlements, with Jews prominent in trade and lease holding. The third chapter very briefly introduces the framework in which revenues were extracted from the estates: direct management, mortgage, the leasing of estates or of monopoly rights: the propinacja, milling, and customs and duties.

Among these, the leasing of estates would be the least popular among Jews, as it pitted the leaseholder against peasants, Christian town dwellers, as well as the lower ranks of the nobility. The remarkable case of the Ickowicz brothers, described in the following, gripping chapter, illustrates the remarkable wealth and position of power 